\title{
General Characteristics of the Intracellular Myrosinase from Aspergillus niger ${ }^{\dagger}$
}

\author{
Masaru OHtsuru and Tadao Hata \\ Research Institute for Food Science, Kyoto University, Kyoto \\ Received May 28, 1973
}

\begin{abstract}
The enzymatic properties of intracellular myrosinase produced by Aspergillas niger AKU 3302 were investigated. Maximum activity occurred at $\mathrm{pH}$ 6.2, and the enzyme was stable in a pH range of 7.6 to 8.0 at $5^{\circ} \mathrm{C}$ for $24 \mathrm{hr}$. Optimum temperature was about $34^{\circ} \mathrm{C}$. Enzyme activity was stimulated by copper (I), (II), manganese (II) and cobalt (II) and was inhibited by mercury (II) and stannous (II) ions. However, metal complexing agents and DFP had little effect, while PCMB was a strong inhibitor. In contrast to plant myrosinase, this enzyme was neither activated nor inhibited by L-ascorbic acid. Glucosides and $\delta$-gluconolactone inhibited enzyme activity but sugars were ineffective. The $K m$ value for sinigrin was $3.3 \%$ $10^{-3} \mathrm{M}$ and that for $p$-nitrophenyl $\beta$-glucoside was $1.5 \times 10^{-3} \mathrm{M}$. The relation between fungous myrosinases and $\beta$-glucosidase is discussed in comparison to plant myrosinase.
\end{abstract}

In a previous paper, ${ }^{11}$ Aspergillus niger AKU 3302, which produces myrosinase, was found through a screening test and its culture conditions were determined. The instability of this intracellular myrosinase was also reported.

There are several papers on the properties of plant myrosinase $\mathrm{e}^{2 \sim 4)}$ and on extracellular myrosinase ${ }^{5,6)}$ produced by Aspergillus sydowi but the nature of intracellular myrosinase from microorganisms is not yet undetermined. There is only the report by Reese et al. ${ }^{6}$ ' who pointed out the existence of intracellular myrosinase in the mycelia of fungus.

In this paper, we describe the general characteristics of the intracellular myrosinase produced by Asp. niger and compare them with characteristics of plant and extracellular myrosinases. The relationship of fungous and plant myrosinases to $\beta$-glucosidases is also discussed.

$\dagger$ This work is part $\mathrm{V}$ in the series, Studies on Fungous Myrosinase. A part of this work was presented at the Annual Meeting of the Agricultural Chemical Society of Japan, Tokyo, April 1969.

Abbreviations: $p$-NPG, $p$-Nitrophenyl $\beta$-glucoside; ASA, L-Ascorbic acid; C.S.L., Corn Steep Liquor; DFP, Diisopropylfluorophosphate; PCMB, $p$-Chloromercuribenzoate; EDTA, Ethylenediaminetetraacetic Acid.

\section{MATERIALS AND METHODS}

Strain. Aspergillus niger AKU 3302 was kindly supplied by the Faculty of Agriculture of Kyoto University and was used as the enzyme source.

Culture. The strain was inoculated in a preculture medium (1.0 liter) containing $5 \%$ malt extract, $2 \%$ sucrose, $0.2 \%$ potassium dihydrogen phosphate, $0.1 \%$ ammonium sulfate, $0.03 \%$ sodium nitrate and $0.03 \%$ magnesium sulfate (as $\mathrm{MgSO}_{4} \cdot 7 \mathrm{H}_{2} \mathrm{O}$ ) at $\mathrm{pH}$ 6.5. Incubation was carried out at $29^{\circ} \mathrm{C}$ for 2 days under reciprocal shaking. The pre-culture was then inoculated into a 40-liter jar fermentor containng 30 liter of medium. The culture medium containied $10 \%$ mustard extract, ${ }^{11} 0.1 \%$ L-ascorbic acid, $0.1 \%$ C.S.L. and $0.03 \% \mathrm{CoCl}_{2} \cdot 6 \mathrm{H}_{2} \mathrm{O}$ in tap water at $\mathrm{pH} 7.0$. Incubation was carried out at $29^{\circ} \mathrm{C}$ for $36 \mathrm{hr}$ with aeration.

Enzyme preparation. The grown mycelia were harvested in a basket centrifuge, and washed twice with water. The collected mycelia were ground with sea sand in $0.1 \mathrm{~m}$ sodium phosphate buffer, $\mathrm{pH} 7.8$, containing $0.01 \mathrm{M} \mathrm{2-mercaptoethanol} \mathrm{and} 0.001 \mathrm{M} \mathrm{L-}$ ascorbic acid after which the whole was centrifuged. The supernatant was used as the crude enzyme preparation.

Substrate. Sinigrin was prepared from yellow mustard seed ${ }^{2,7}$ and was used as the substrate of fungous myrosinase. $p$-Nitrophenyl $\beta$-glucoside was of an analytical grade. 
Assay of sinigrin hydrolysis. The assay mixture contained $2.5 \mu$ moles of sinigrin and enzyme in a total volume of $1 \mathrm{ml}$. Enzymatic activities were determined by measuring liberated glucose and by titrating liberated sulfate at $\mathrm{pH} 6.2$ and $34^{\circ} \mathrm{C}$ for $20 \mathrm{~min}$, as described previously.2,5) The reaction was conducted under conditions regarded to be those for zero order reactions.

Assay of $p-N P G$ hydrolysis. The assay mixture contained $1 \mu$ mole of $p$-NPG $0.1 \mu$ mole of phosphate buffer, pH 6.2 and the enzyme in a total volume of $1 \mathrm{ml}$. The reaction was carried out at $34^{\circ} \mathrm{C}$ for $10 \mathrm{~min}$ under conditions regarded to be those for zero order reactions. After the reaction was over, $5 \mathrm{ml}$ of $8 \%$ aqueous dipotassium hydrogen phosphate solution was added to the reaction mixture. Liberated $p$-nitrophenol was measured colorimetrically at $400 \mathrm{~m} \mu$ using a Shimadzu Model QV-50 spectrophotometer.

Effects of various reagents. Reagents and enzyme were incubated at $\mathrm{pH} 6.2$ and $34^{\circ} \mathrm{C}$ for $20 \mathrm{~min}$ before each experiment. Enzymatic reactions were initiated by the addition of substrate.

Assay of protein. Protein concentrations were determined by the method of Lowry et al. ${ }^{8}$

\section{RESULTS}

Partial purification of the fungous myrosinase Chromatography on DEAE-Sephadex. The crude enzyme solution $(500 \mathrm{ml}$, total protein $1050 \mathrm{mg}$ ) was dialyzed against $0.01 \mathrm{M}$ phosphate buffer containing $0.01 \mathrm{M}$ 2-mercaptoethanol and $0.001 \mathrm{~m}$ ascorbic acid, $\mathrm{pH} 7.8$, and then was charged on a DEAE-Sephadex column $(4.5 \times 23 \mathrm{~cm})$ which was eqilibrated with the same buffer. Elution of protein was performed with a linear gradient of 0.05 to $0.5 \mathrm{M}$ sodium chloride in the same buffer. Myrosinase activity could not be separated completely from $\beta$-glucosidase activity (Fig. 1). The myrosinase in this step, however, was almost inactivated during dialysis and salting out with ammonium sulfate and was protected neither by the stabilizer (2-mercaptoethanol and ascorbic acid) of the crude preparation nor by any of reagents tested. But, the enzyme was only stable during concentrating with polyethylene glycol $\# 6,000$, further purification was done by an isoelectric focusing. Fractions indicated by the horizontal arrow

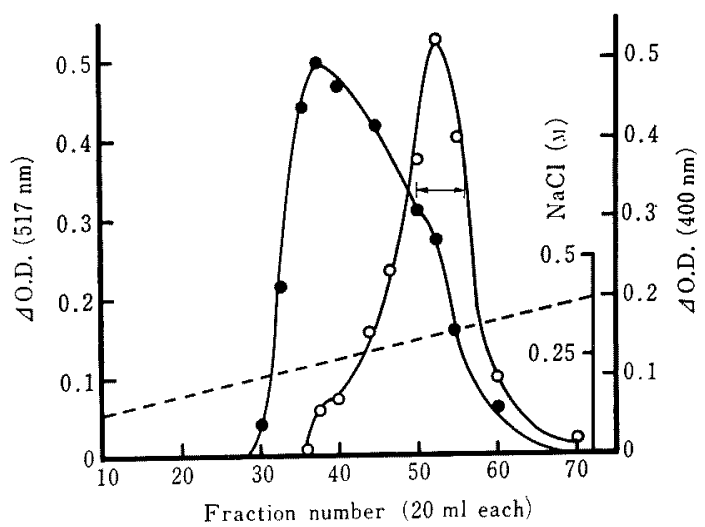

Fig. 1. Chromatogram of Fungous Myrosinase on a DEAE-Sephadex Column.

(O) Myrosinase activity and (•) $\beta$-Glucosidase activity (---) $\mathrm{NaCl}$ concentration.

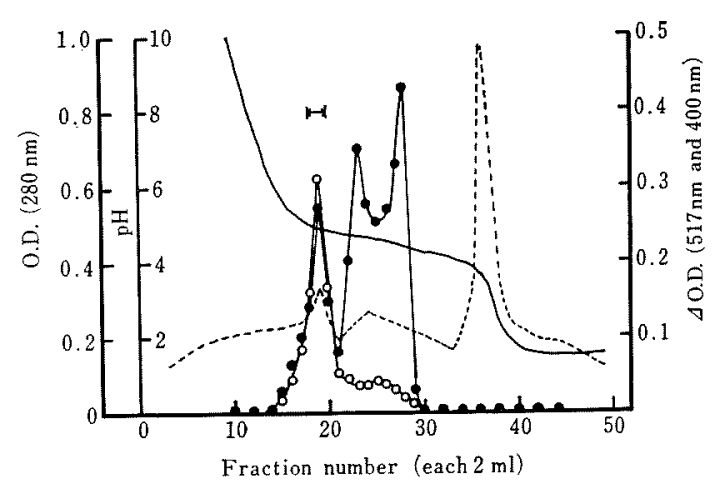

FIG. 2. Isoelectrofocusing of the Partial Purified Enzyme.

The sample solution was isoelectrically focused on the LKB Column containing carrier ampholyte with a pH range of 4 to 6 .

(O) Sinigrin hydrolysis, (๑) $p$-NPG hydrolysis, (-) pH and (--) O.D. at $280 \mathrm{~m} \mu$.

in Fig. 2 were pooled and concentrated by polyethylene glycol.

Isoelectric focusing. Isoelectric focusing was carried out by the method of Vesterberg and Svensson, ${ }^{91}$ using the LKB column $(110 \mathrm{ml})$ containing carrier ampholyte and glycerol. The $\mathrm{pH}$ range of the ampholyte used was from 4 to 6 . Ampholyte in the column amounted to $1 \mathrm{~g}$. The anode compartment contained glycerol $(60 \% \mathrm{v} / \mathrm{v})$, to which $0.2 \mathrm{ml}$ of phosphoric acid was added. The enzyme concentrated $(50 \mathrm{mg}$ protein, 
Table I. Summary of Partial Purification of Fungous Myrosinase

\begin{tabular}{|c|c|c|c|c|c|c|}
\hline \multirow{2}{*}{ Treatment } & \multirow{2}{*}{$\begin{array}{l}\text { Volume } \\
\text { (ml) }\end{array}$} & \multicolumn{2}{|c|}{$\begin{array}{c}\text { Activity } \\
(\mu \mathrm{moles} / \mathrm{min} / \mathrm{ml})\end{array}$} & \multicolumn{2}{|c|}{$\begin{array}{l}\text { Specific activity } \\
(\mu \text { moles/min/mg) }\end{array}$} & \multirow{2}{*}{$\begin{array}{l}\text { Protein } \\
(\mathrm{mg} / \mathrm{ml})\end{array}$} \\
\hline & & $\begin{array}{c}\text { Sinigrin } \\
\text { hydrolysis }\end{array}$ & $\begin{array}{c}p \text {-NPG } \\
\text { hydrolysis }\end{array}$ & $\begin{array}{l}\text { Sinigrin } \\
\text { hydrolysis }\end{array}$ & $\begin{array}{l}p \text {-NPG } \\
\text { hydrolysis }\end{array}$ & \\
\hline Crude enzyme & 500 & 0.291 & 0.447 & 0.139 & 0.213 & 2.10 \\
\hline Dialysate & 510 & 0.270 & 0.391 & 0.134 & 0.195 & 2.02 \\
\hline $\begin{array}{l}\text { Chromatography on } \\
\text { DEAE-Sephadex }\end{array}$ & 140 & 0.336 & 0.254 & 0.84 & 0.635 & 0.4 \\
\hline $\begin{array}{l}\text { Concentration with } \\
\text { Polyethylene glycol }\end{array}$ & 20 & 1.68 & 1.429 & 0.672 & 0.572 & 2.5 \\
\hline Isoelectric focusing & 6 & 0.543 & 0.164 & 1.916 & 0.58 & 0.283 \\
\hline
\end{tabular}

about $20 \mathrm{ml}$ ) was applied to the column. The column was controlled at $4^{\circ} \mathrm{C}$ by circulating chilled water. The run was performed with a maximum load of $0.5 \mathrm{~W}$, implying a final voltage of approximately $350 \mathrm{~V}$. After focusing for $72 \mathrm{hr}$, fractions of each $2 \mathrm{ml}$ were removed from the column and their enzyme activities were determined. In Fig. 2, typical isoelectrofocusing pattern is shown. There were some $\beta$-glucosidase activities for $p$-NPG besides myrosinase. The pI value of the myrosinase was about $\mathrm{pH} 4.8$, the same as plant myrosinase. Fractions indicated by the horizontal arrow were pooled and used in the following experiments. A summary of the partial purification steps of the enzyme is shown in Table I. It also shows that fungous myrosinase is remarkably unstable.

General characteristics of the fungous myrosinase. Figures 3, 4, 5 and 6 show the $\mathrm{pH}$ activity, pH-stability, temperature-stability and optimum-temperature curves, respectively. Optimum $\mathrm{pH}$ was about $\mathrm{pH}$ 6.2. The enzyme was most stable at $\mathrm{pH} 7.8$ and at $5^{\circ} \mathrm{C}$. Optimum temperature was at $34^{\circ} \mathrm{C}$.

Effects of various reagents. Copper (I), (II), manganese (II) and cobalt (II) ions stimulated enzyme activity at $10^{-3} \mathrm{M}$; whereas, mercury (II) and stannous (II) ions inhibited it (Table II). PCMB was a strong inhibitor (Table III). DFP, iodoacetate and metal complexing agents showed little effect.

Plant myrosinase ${ }^{2)}$ is specifically activated by ascorbic acid $\left(10^{-3} \mathrm{M}\right)$, while, intracellular

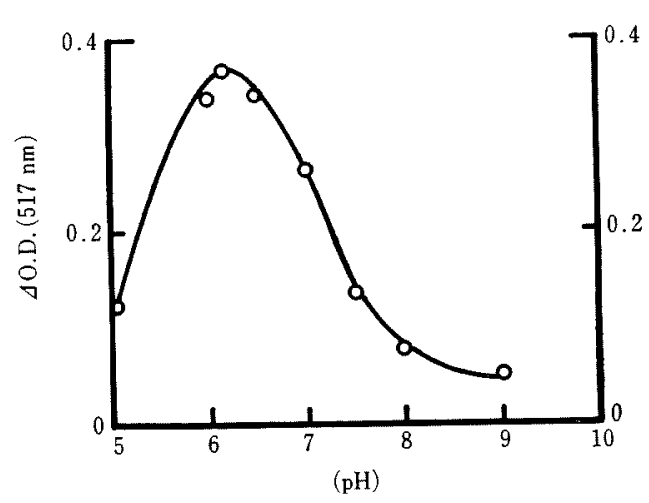

FIG. 3. pH-Activity Curve of Fungous Myrosinase. $0.2 \mathrm{M}$ Sodium phosphate buffer $(\mathrm{pH} 6.0 \sim 9.0$ ) and $0.2 \mathrm{M}$ acetate buffer (pH 5.0) were used.

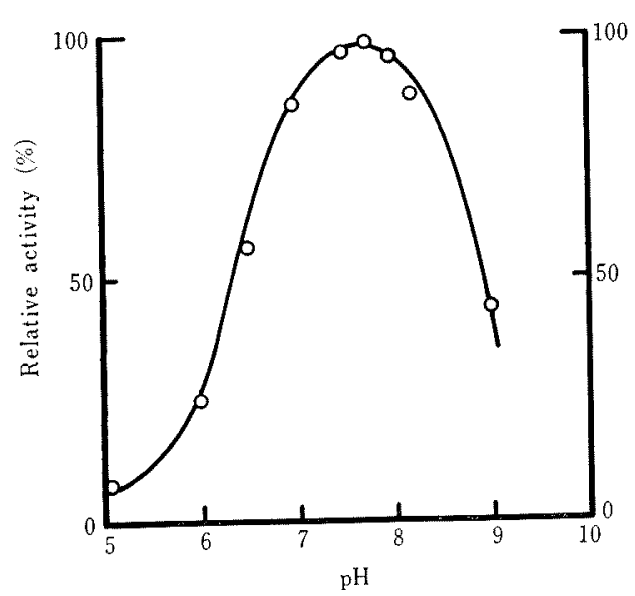

FIG. 4. pH-Stability Curve of Fungous Myrosinase.

The sample solution was incubated in $0.05 \mathrm{M}$ sodium phosphate buffer (pH 6 9) and acetate buffer ( $\mathrm{pH}$ 5.0) for $24 \mathrm{hr}$ at $5^{\circ} \mathrm{C}$.

Reactions were carried out at $\mathrm{pH} 6.2$ and $34^{\circ} \mathrm{C}$. 


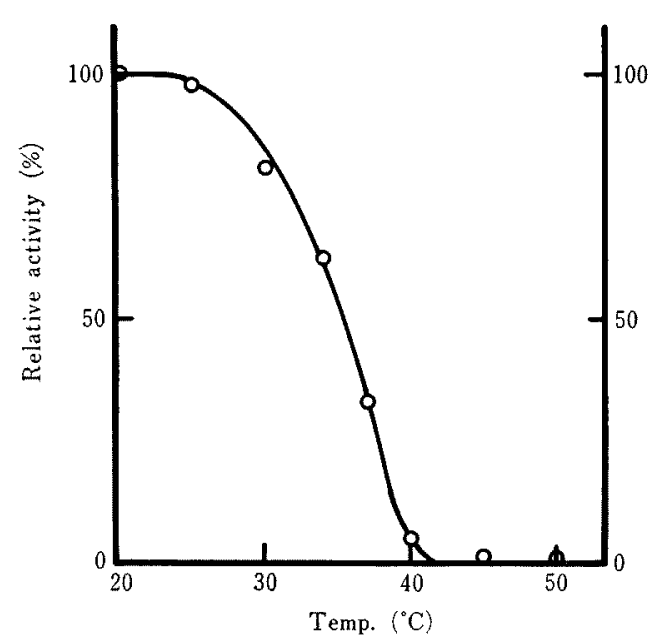

Frg. 5. Heat-stability Curve of Fungous Myrosinase. The sample solution was incubated in $0.1 \mathrm{M}$ phosphate buffer, pH 7.8 for $20 \mathrm{~min}$ at each temperature before measurement of enzyme activity.

myrosinase was neither activated nor inhibited by L-ascrobate.

$\delta$-Gluconolactone, a specific inhibitor of $\beta$-glucosidase, ${ }^{10)}$ inhibited enzyme activity.

Effects of sugars and glucosides. Sugar and glucoside effects on intracellular myrosinase were tested (Table IV). None of the sugars tested had any effect, but glucosides inhibited activity by about $20 \sim 30 \%$.

\section{Table II. EfFect of Inorganic Salts on Fungous Myrosinase}

Reactions were carried out at $\mathrm{pH} 6.2$ and $34^{\circ} \mathrm{C}$. All inorganic salts were pre-incubated at $10^{-3} \mathrm{M}$.

\begin{tabular}{lc}
$\begin{array}{c}\text { Inorganic salts } \\
\left(10^{-3} \mathrm{M}\right)\end{array}$ & $\begin{array}{c}\text { Relative activity } \\
(\%)\end{array}$ \\
\hline $\mathrm{None}$ & 100 \\
$\mathrm{KCl}$ & 95 \\
$\mathrm{LiCl}$ & 99 \\
$\mathrm{CuCl}$ & 140 \\
$\mathrm{CuCl}$ & 132 \\
$\mathrm{MnCl}_{2}$ & 170 \\
$\mathrm{CoCl}_{2}$ & 186 \\
$\mathrm{MgCl}_{2}$ & 77 \\
$\mathrm{ZnCl}_{2}$ & 72 \\
$\mathrm{SnCl}_{2}$ & 34 \\
$\mathrm{HgCl}_{2}$ & 5 \\
$\mathrm{FeCl}_{2}$ & 90 \\
$\mathrm{FeCl}_{3}$ & 74 \\
\hline
\end{tabular}

Table III. EFfect of Various Reagents on Fungous MYrosinase

PCMB was pre-incubated at $6 \times 10^{-5} \mathrm{M}$; others, at $10^{-3} \mathrm{M}$.

\begin{tabular}{lcc}
\hline & Conc. (M) & Relative activity (\%) \\
\hline None & & 100 \\
PCMB & $6 \times 10^{-5}$ & 9 \\
Iodoacetate & $10^{-3}$ & 80 \\
EDTA & $10^{-3}$ & 80 \\
o-Phenanthroline & $10^{-3}$ & 73 \\
Ascorbic acid & $10^{-3}$ & 98 \\
KI & $10^{-3}$ & 91 \\
NaBr & $10^{-3}$ & 84 \\
DFP & $10^{-3}$ & 82 \\
o-Gluconolactone & $10^{-3}$ & 38 \\
\hline
\end{tabular}

Table IV. Effect of Various Sugars and Glucosides on Fungous Myrosinase

Reactions were carried out at pH 6.2 and $34^{\circ} \mathrm{C}$. Enzyme activity was measured by the liberation of sulfate. Amygdalin and $p$-NPG were pre-incubated at $2 \times 10^{-2} \mathrm{M}$ and $5 \times 10^{-2} \mathrm{M}$, respectively; others at $10^{-1} \mathrm{M}$.

\begin{tabular}{|c|c|c|}
\hline \multicolumn{2}{|c|}{ Sugar or glucoside $(0.1 \mathrm{M})$} & \multirow{2}{*}{$\frac{\text { Relative activity }(\%)}{100}$} \\
\hline None & & \\
\hline Glucose & & 104 \\
\hline Galactose & & 103 \\
\hline Maltose & & 101 \\
\hline Fructose & & 107 \\
\hline Xylose & & 105 \\
\hline Salicin & & 85 \\
\hline Arbutin & & 79 \\
\hline Amygdalin & $2 \times 10^{-2} \mathrm{M}$ & 86 \\
\hline$p \cdot N P G$ & $5 \times 10^{-2} \mathrm{M}$ & 106 \\
\hline
\end{tabular}

Kinetic studies. Figure 7 shows the Lineweaver-Burk plot for intracellular myrosinase. $K m$ value for sinigrin was calculated to be $3.3 \times 10^{-3} \mathrm{M}$.

In order to prove that $p$-NPG was hydrolyzed by catalytic action of the fungous myrosinase itself, as described by Levvy and Mash, ${ }^{11}$ the inhibitory effect of the specific substrate, sinigrin, on $p$-NPG hydrolysis was tested. Results are shown in Fig. 8. It is evident from this figure that $p$-NPG hydrolysis was inhibited competitively by sinigrin. The $K m$ value for $p$-NPG and $K i$ value for sinigrin were calculated to be $1.5 \times 10^{-3} \mathrm{M}$ and $3.8 \times$ $10^{-3} \mathrm{M}$, respectively. This $K i$ value is in good 
Table V. Comparison of Some Properties of Myrosinases FROM VARIOUS ORIGINS

\begin{tabular}{lccc}
\hline & Asp.niger & Asp. sydowi & Plant \\
\hline pH-activity & 6.2 & 7 & $5 \sim 7$ \\
pH-stability & 7.8 & $6 \sim 9$ & $4 \sim 9$ \\
Heat-stability & $25^{\circ} \mathrm{C}$ & $45^{\circ} \mathrm{C}$ & $55^{\circ} \mathrm{C}$ \\
PCMB & inhibit & no effect & inhibit \\
Ascorbic acid & no effect & no effect & activate \\
Metal & activate & activate & $\left(\mathrm{Co}^{2+}\right)$ \\
& $\left(\mathrm{Cu}^{+}, \mathrm{Cu}^{2+}, \mathrm{Mn}^{2+}, \mathrm{Co}^{2+}\right)$ & inhibit & inhibit \\
& inhibit & $\left(\mathrm{Hg}^{2+}, \mathrm{Fe}^{2+}\right)$ & $\left(\mathrm{Hg}^{2+}, \mathrm{Cu}^{2+}\right)$ \\
$K m$ for Sinigrin & $\left(\mathrm{Hg}^{2+}, \mathrm{Sn}^{2+}\right)$ & $3.6 \times 10^{-3} \mathrm{M}$ & $1.8 \times 10^{-4} \mathrm{M}$ \\
$K i$ for Sinigrin & $3.3 \times 10^{-3} \mathrm{M}$ & $3.8 \times 10^{-3} \mathrm{M}$ & $2.0 \times 10^{-4} \mathrm{M}$ \\
$K m$ for $p$-NPG & $3.8 \times 10^{-3} \mathrm{M}$ & $1.0 \times 10^{-4} \mathrm{M}$ & $2.0 \times 10^{-3} \mathrm{M}$ \\
\hline
\end{tabular}

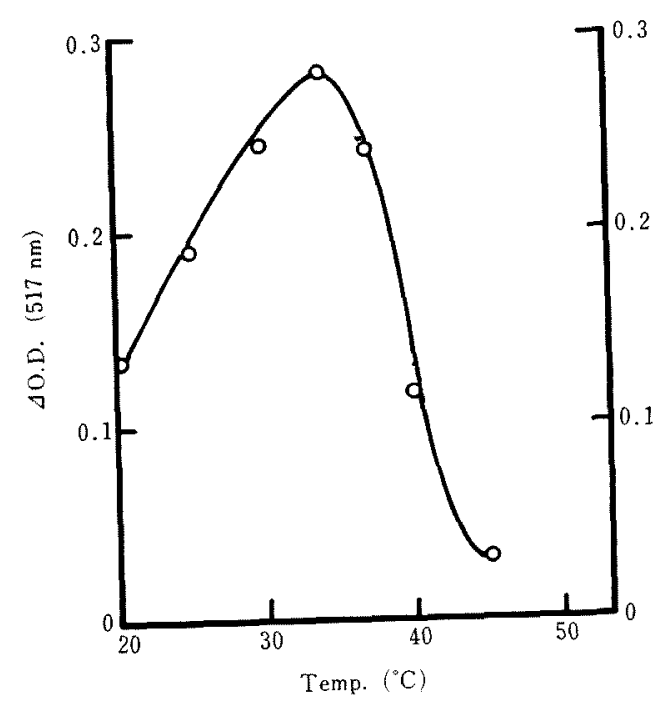

FIG. 6. Optimum-temperature Curve of Fungous Myrosinase.

Reactions were carried out at $\mathrm{pH} 6.2$ for $20 \mathrm{~min}$.

agreement with the $K m$ value for sinigrin $\left(3.3 \times 10^{-3} \mathrm{M}\right)$ of the enzyme.

\section{DISCUSSION}

General characteristics of intracellular myrosinase produced by Aspergillus niger AKU 3302 were investigated. There were some $\beta$-glucosidase activities for $p$-NPG in the mycelia of Asp. niger, besides myrosinase. As described previously, ${ }^{1}$ the myrosinase produced by Asp. niger was remarkably un-

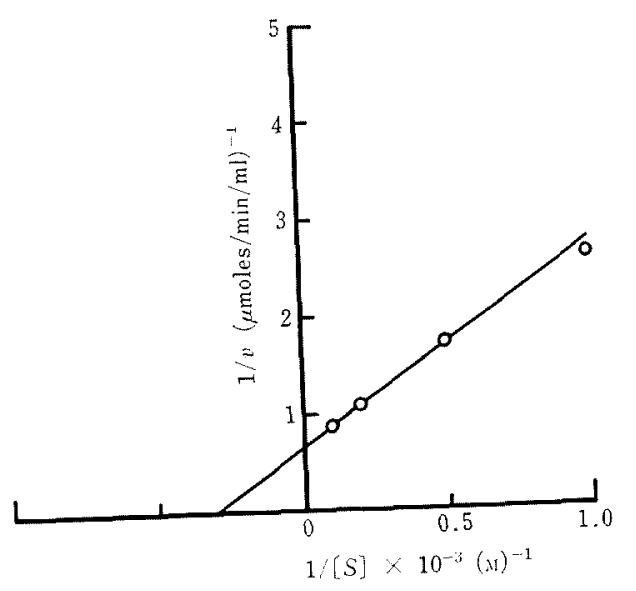

FrG. 7. Reciprocal Plot of Sinigrin Hydrolysis.

stable and became more so after chromatography on DEAE-Sephadex. This myrosinase was not protected by stabilizing reagents for the crude preparation.

Some properties of Asp. niger, Asp. sydowi and plant myrosinases were compared (Table V). Asp. niger myrosinase was less stable than the others to heat, acid and alkali, and to chemicals. It was strongly inhibited by PCMB. The Asp. sydowi myrosinase prepared by the authors was not inhibited by PCMB but its inhibition has been reported by Reese et al. ${ }^{6)}$

Asp. niger myrosinase was activated by cobalt (II) and manganese (II) and was inhibited by mercury (II). However, metal com- 


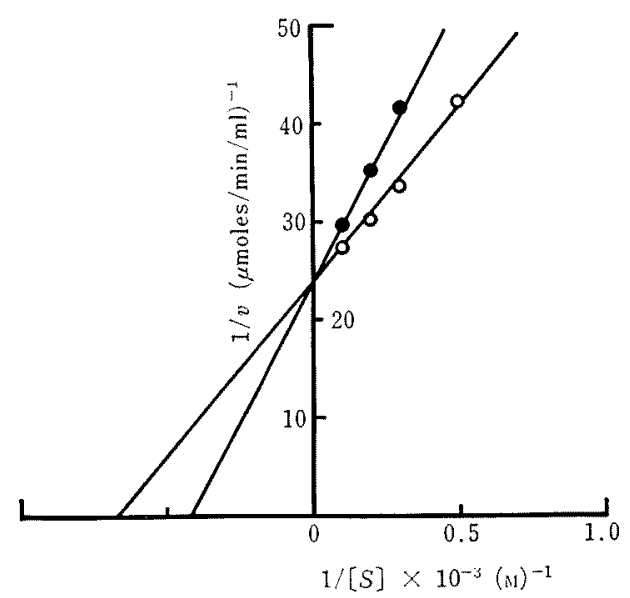

FIG. 8. Inhibitory Effect of Sinigrin on $p$-NPG Hydrolysis.

Reactions were carried out in the presence (0) and absence $(\mathrm{O})$ of $2.5 \mathrm{~mm}$ sinigrin at $\mathrm{pH} 6.2$ and $34^{\circ} \mathrm{C}$.

plexing agents (EDTA and o-phenanthlorine) only slightly inhibited the activity. Thus, the role of metal ions to the enzyme is still unsolved.

$K m$ value for the sinigrin of fungous myrosinases are considered to be larger than that for $p-\mathrm{NPG}$, i.e. fungous myrosinases are thought to have a greater affinity for $p$-NPG, whereas plant myrosinase has a greater affinity for sinigrin than for $p$-NPG. Thus, Asp. niger myrosinase is also thought to be a $\beta$-glucosidase, which has high affinity for mustard oil glucoside. Pigman, ${ }^{12}$ Nagashima and Uchiyama, ${ }^{13,14)}$ and the authors ${ }^{4)}$ have reported that plant myrosinase is a member of the $\beta$-glucosidase. The above results support this conclusion. Plant myrosinase is highly specified for mustard oil glucosides, whereas fungous myrosinases are less specific than the plant enzyme. Even so, fungous myrosinases have higher affinities for mustard oil glucosides than for the usual $\beta$-glucosidases. This conclusion is supported by the fact that fungous myrosinase was produced only in the presence of mustard extract.

\section{REFERENCES}

1) M. Ohtsuru, I. Tsuruo and T. Hata, Agr. Biol. Chem., 37, 967 (1973).

2) I. Tsuruo, M. Yoshida and T. Hata, ibid., 31, 18 (1967).

3) I. Tsuruo and T. Hata, ibid., 32, 479 (1968).

4) idem, ibid., 32, 1420 (1968).

5) M. Ohtsuru, I. Tsuruo and T. Hata, ibid., 33, 1309 (1969).

6) E. T. Reese, R. C. Clapp and M. Mandels, Arch. Biochem. Biophys., 75, 228 (1958).

7) Z. Nagashima and M. Uchiyama, Nippon Nogeikagaku Kaishi, 33, 478 (1959).

8) O. H. Lowry, N. T. Rosebrough, A. L. Farr and R. T. Randall, J. Biol. Chem., 193, 265 (1951).

9) O. Vesterberg and H. Svensson, Acta Chem. Scand., 20, 820 (1966).

10) J. Conchie and G. A. Levvy, Biochem. J., 65, 398 (1957).

11) G. A. Levvy and C. A. Mash, Science, 119, 337 (1954).

12) W. W. Pigman, J. Res. Natl. Bur. Stand., 26, 197 (1941).

13) Z. Nagashima and M. Uchiyama, Nippon Nogeikagaku Kaishi, 33, 1144 (1959).

14) Z. Nagashima and M. Uchiyama, Bull. Agr. Chem. Soc. Japan, 23, 555 (1959). 